\title{
Effectiveness of microbial phytases in diets of sows during gestation and lactation
}

\author{
K. Männer ${ }^{1}$ and O. Simon \\ Institute of Animal Nutrition, Free University Berlin, Faculty of Veterinary Medicine \\ Brümmerstraße 34, D-14195 Berlin
}

(Received 9 June 2005; revised version 25 January 2006; accepted 12 April 2006)

\begin{abstract}
The effect of two microbial phytases of fungal origin (Peniophora and Consensus phytase) were evaluated for their effectiveness in improving performance and digestibility of $\mathrm{P}$ and $\mathrm{Ca}$. A total of 44 multiparous sows were used during gestation (days 28 to 69) and lactation (days 1 to 19). Gestating and lactating sows were fed adequate P ( 9.9 and 27 g P per day) or low P diets ( 7.6 and 15.9 g per day) with or without supplementation of Peniophora (pregnancy) or Consensus phytase (lactation) providing 500, 750 and 1000 or 500 and 1000 units per kg diet, respectively. The obtained data generally indicated that graded levels of both phytases were effective in improving apparent phosphorus digestibility during gestation or lactation. The additional phosphorus release achieved when administering the recommended supply of Peniophora phytase (750 PPU $/ \mathrm{kg}$ feed) was 0.1 $\mathrm{g} / \mathrm{kg}$ feed in gestating sows, which is equivalent to $0.6 \mathrm{~g}$ of monocalcium-phosphate. Consensus phytase administered at the recommended dosage of 500 units per $\mathrm{kg}$ for lactating sows provided a release of $0.6 \mathrm{~g}$ P per kg feed from phytate, which corresponds to $2.5 \mathrm{~g}$ monocalcium-phosphate. The effectiveness of the studied phytases in pregnant or lactating sows is comparable to that in growing pigs.
\end{abstract}

KEY WORDS: sows, microbial phytase, apparent digestibility, phosphorus, calcium

\section{INTRODUCTION}

Phosphorus (P) is an essential element involved in energy metabolism and is necessary for bone mineralization, fertility and performance (Poulsen et al., 1999). In pig feeding, dietary $P$ originates mainly from plants and feed phosphates. The major fraction of plant $\mathrm{P}$ is present as phytate-P, which is also

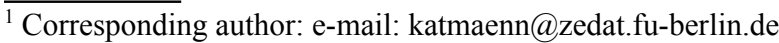


the main storage form of plant $\mathrm{P}$ and inositol (Erdman, 1979). The phytate-P proportion in feedstuffs for sows varies between 30 and $80 \%$ of the total $\mathrm{P}$ (Eeckhout and DePaepe, 1994). Single-stomached animals have only marginal host phytase activity, which means that such animals are unable to effectively degrade phytate in the digestive tract (Maga, 1982). The ability to hydrolyse phytate-P is, therefore, dependent on the endogenous phytases in feedstuffs, which vary from 0 to 5000 PPU/kg dry matter (Eeckhout and DePaepe, 1994), and on the microbial activity in the upper digestive tract. The total digestible P in feedstuffs varies between 6 and 95\% (Jongbloed and Kemme, 2002). This wide range is caused mainly by differences in phytate-P, phytase activity and the proportion of $\mathrm{Ca}$ to $\mathrm{P}$. The system of $\mathrm{P}$ recommendations was therefore adapted to diet formulations based primarily on inorganic plant $\mathrm{P}$ and non-plant sources. The poor digestive utilization of phytic acid $\mathrm{P}$ and its consequences for diet costs, the environment and digestibility of minerals have led to extensive research efforts directed at improving phytate $\mathrm{P}$ degradation. Such research has clearly demonstrated that phytases (myo-inositol-hexakisphosphohydrolase, E.C.3.1.3.8 or E.C.3.1.3.26) and specific phosphohydrolases, which degrade phytate to yield inositol triphosphate or even monophosphate and orthophosphate as final products via inositol penta- or monophosphates as intermediary products, have merit as a tool for minimizing P excretion by increasing P availability and, therefore, subsequent utilization. In order to reduce environmental pollution and with regard to the limited availability of $\mathrm{P}$ sources after banning animal feedstuffs, phytases are usually supplemented in diets for poultry, piglets and fattening pigs and replace to some extent inorganic $\mathrm{P}$ (van der Klis and Versteegh, 2001; Jongbloed and Kemme, 2002). Only very few reports, however, have been published on the effectiveness of phytases in gestating and lactating sows (Kemme et al., 1997; Jongbloed et al., 2004; Liesegang et al., 2005).

In this study, a Peniophora phytase, which is already authorized for use as a feed additive, and a developmental phytase (Consensus phytase) were evaluated in regards to effectiveness in improving performance and digestibility of $\mathrm{Ca}$ and $\mathrm{P}$ in sows whose diets were high in phytate $\mathrm{P}$ but low in phytase activity. In contrast to the most frequently applied Aspergillus phytases, which are 3phytases, Peniophora phytase is a 6-phytase initiating phytate degradation by hydrolysis of the ester bond at position 6 of the inositol ring. The Consensus phytase is encoded by a synthetic gene constructed on the basis of fungal phytase genes for high thermostability (Lehmann et al., 2000). The high heat stability of this construct was shown under laboratory and pelleting conditions (Simon and Igbasan, 2002). 


\section{MATERIAL AND METHODS}

\section{Animals and experimental design}

A total of 20 sows in the same reproduction stage ( $28^{\text {th }}$ to $69^{\text {th }}$ day of pregnancy) and 24 sows ( $1^{\text {st }}$ to $19^{\text {th }}$ day of lactation) with the same genotype of the hybrid line Landrace x Duroc, obtained from the Institute's own herd were used. All pregnant sows were multiparous in their $4^{\text {th }}$ or $5^{\text {th }}$ parity whilst those in lactation had their $2^{\text {nd }}$ or $3^{\text {rd }}$ litter. The trial with pregnant sows was organized in three consecutive periods of 14 days each. In the pre-treatment period all sows received a low $\mathrm{P}$ diet in order to encourage optimal $\mathrm{P}$ absorption and minimal $\mathrm{P}$ excretion. In the treatment period the sows received diets with either adequate $\mathrm{P}$ (positive control, group A) or low $\mathrm{P}$ plus the Peniophora phytase at graded levels (groups $\mathrm{B}, \mathrm{C}$ and D). In order to estimate or exclude possible effects of the advancing state of pregnancy on the apparent $\mathrm{P}$ and $\mathrm{Ca}$ digestibility, all sows in the posttreatment period once again received the low $\mathrm{P}$ diet without phytase. Diets during the lactation period were labelled as adequate $\mathrm{P}$ and low $\mathrm{P}$ diets without or with the evolved Consensus phytase. Details are given in Tables 1 and 2.

Table 1. Experimental design for the response of Peniophora phytase during pregnancy

\begin{tabular}{|c|c|c|c|c|c|}
\hline Groups & & A & $\mathrm{B}$ & $\mathrm{C}$ & $\mathrm{D}$ \\
\hline Sows & & 5 & 5 & 5 & 5 \\
\hline Pre-treatment $\left(28^{\text {th }}\right.$ to $41^{\text {st }}$ day $)$ & & \multicolumn{4}{|c|}{ low $\mathrm{P}$} \\
\hline Treatment $\left(42^{\text {nd }}\right.$ to $55^{\text {th }}$ day $)$ & & adequate $\mathrm{P}$ & & low $\mathrm{P}$ & \\
\hline Peniophora phytase & $\mathrm{PPU} / \mathrm{kg}$ & 0 & 500 & 750 & 1000 \\
\hline Post-treatment $\left(56^{\text {th }}\right.$ to $69^{\text {th }}$ day) & & \multicolumn{4}{|c|}{ low $\mathrm{P}$} \\
\hline
\end{tabular}

Table 2. Experimental design for the response of Consensus phytase during lactatation

\begin{tabular}{|c|c|c|c|c|c|}
\hline Treatment & & A & $\mathrm{B}$ & $\mathrm{C}$ & $\mathrm{D}$ \\
\hline Sows & & 6 & 6 & 6 & 6 \\
\hline Diet P & & \multicolumn{2}{|c|}{ adequate } & \multicolumn{2}{|c|}{ low } \\
\hline Consensus phytase & PPU/kg & 0 & 0 & 500 & 1000 \\
\hline
\end{tabular}

Gestating sows were housed in pens with individual feeding, self catching device and dung floor cleaner. During lactation sows were kept in single cages with a farrowing rail on a perforated sheet floor. Light and climate were controlled in both stables. The temperature was maintained at $21 \pm 2^{\circ} \mathrm{C}$. For piglets electric infra-red heaters were installed in order to maintain a local bedding temperature of $30^{\circ} \mathrm{C}$ during the first 14 days of life. The relative humidity was in the range of $65 \%$. 
Diets

All diets were formulated in accordance with the recommendations of the German Society of Nutrition Physiology (GfE, 1987, 1997), with the exception of $\mathrm{P}$, and were offered in mash form. In order to minimize the phytase activity of feed components with an expected high phytase activity (wheat bran, barley), the feed was heat treated in the conditioner of a pelleting machine at a steam temperature of $80^{\circ} \mathrm{C}$ prior to mixing. The intrinsic phytase activity in the basal diets was 30 $\mathrm{PPU} / \mathrm{kg}$ feed, which is negligible. The analysed P content in the adequate or low $\mathrm{P}$ diets for gestating sows was 4.7 and $3.6 \mathrm{~g}$ per kg feed, respectively. Low P diets were either prepared without phytase (negative control) for the pre- and posttreatment period or with phytase for the treatment period. Based on literature data (Jongbloed and Kemme, 1990; GfE, 1997) and on a daily feed intake of $2.1 \mathrm{~kg}$ the available P supply was 4.2 and $2.1 \mathrm{~g}$ per sow and day for the adequate and low $\mathrm{P}$ diets, respectively. The composition and the analysed nutrients are presented in

Table 3. Ingredients and chemical analyses (original matter) of the basal diets for pregnant sows

\begin{tabular}{lcc}
\hline Treatment & Adequate P & Low P \\
\hline Ingredients, \% & & \\
maize & 61.30 & 61.30 \\
soyabean hulls & 23.00 & 23.00 \\
soyabean meal & 6.50 & 6.50 \\
wheat bran & 5.60 & 5.85 \\
limestone & 1.30 & 1.50 \\
Premix & 1.20 & 1.20 \\
$\mathrm{Cr}_{2} \mathrm{O}_{3}$ & 0.50 & 0.50 \\
$\mathrm{MCP}^{2}$ & 0.45 & - \\
$\mathrm{L}^{2}$ lysine & 0.15 & 0.15
\end{tabular}

\begin{tabular}{lcrr} 
Chemical analysis & & & \\
$\mathrm{ME}_{\mathrm{BFS}}$ & $\mathrm{MJ} / \mathrm{kg}$ & 11.75 & 11.76 \\
crude protein & $\mathrm{g} / \mathrm{kg}$ & 131.42 & 135.22 \\
crude fibre & $\mathrm{g} / \mathrm{kg}$ & 109.25 & 109.38 \\
crude fat & $\mathrm{g} / \mathrm{kg}$ & 34.38 & 34.44 \\
$\mathrm{Ca}$ & $\mathrm{g} / \mathrm{kg}$ & 6.94 & 7.11 \\
$\mathrm{P}$ & $\mathrm{g} / \mathrm{kg}$ & 4.74 & 3.62 \\
\hline
\end{tabular}

${ }^{1}$ provided per kg of diet: 12000 IE vit. A; 1500 IE vit. $\mathrm{D}_{3}$; mg: vit. $\mathrm{E} 45$; vit. $\mathrm{K}_{3} 2$; vit. $\mathrm{B}_{1} 2$; vit. $\mathrm{B}_{2}$ 3.0; niacin 12; vit. $\mathrm{B}_{6} 2.5$; $\mu$ g: vit. $\mathrm{B}_{12} 18$; biotin 200; $\mathrm{mg}$ : D-pantothenic acid 12; folic acid 1,5; g: $\mathrm{Na} 2 ; \mathrm{Mg} 1.2 ; \mathrm{mg}$ : Zn 80; Fe 100; Mn 55; Cu 15; J 0.6; Co 1.0; Se 0.2

${ }^{2}$ monocalciumphospate 
Table 4. Ingredients and chemical analyses (original matter) of the basal diets for lactating sows

\begin{tabular}{|c|c|c|c|}
\hline Treatment & & Adequate $\mathrm{P}$ & Low $\mathrm{P}$ \\
\hline Ingredients & $\%$ & & \\
\hline Barley & & 31.52 & 31.52 \\
\hline Maize & & 30.54 & 30.54 \\
\hline soyabean meal & & 30.00 & 30.00 \\
\hline soyabean oil & & 4.03 & 4.03 \\
\hline limestone & & 1.55 & 1.91 \\
\hline Premix $^{1}$ & & 1.20 & 1.20 \\
\hline $\mathrm{MCP}^{2}$ & & 0.82 & - \\
\hline $\mathrm{Cr}_{2} \mathrm{O}_{3}$ & & 0.50 & 0.50 \\
\hline L-Lysine & & 0.24 & 0.24 \\
\hline DL-Methionine & & 0.09 & 0.09 \\
\hline tryptophane & & 0.02 & 0.02 \\
\hline straw meal & & - & 0.46 \\
\hline \multicolumn{4}{|l|}{ Chemical analysis } \\
\hline $\mathrm{ME}_{\mathrm{BFS}}$ & $\mathrm{MJ} / \mathrm{kg}$ & 12.96 & 12.71 \\
\hline crude protein & $\mathrm{g} / \mathrm{kg}$ & 159.6 & 197.10 \\
\hline crude fibre & $\mathrm{g} / \mathrm{kg}$ & 40.50 & 40.91 \\
\hline crude fat & $\mathrm{g} / \mathrm{kg}$ & 62.84 & 62.48 \\
\hline $\mathrm{Ca}$ & $\mathrm{g} / \mathrm{kg}$ & 9.10 & 9.50 \\
\hline $\mathrm{P}$ & $\mathrm{g} / \mathrm{kg}$ & 5.93 & 3.46 \\
\hline
\end{tabular}

1,2 see Table 3

Table 3. The respective diets for lactating sows are given in Table 4. Taking $35 \mathrm{~g} \mathrm{P}$ per sow per day as the adequate level (GfE, 1997), $P$ was calculated with $5.9 \mathrm{~g}$ per $\mathrm{kg}$ feed (positive control). P in low P diets was adjusted to $3.5 \mathrm{~g}$ per $\mathrm{kg}$ diet which was fed with or without the addition of Consensus phytase at 500 or 1000 units per kg of diet. Available P was calculated with $3.1 \mathrm{~g}$ per $\mathrm{kg}$ feed for the adequateand $1.3 \mathrm{~g}$ per $\mathrm{kg}$ feed for the low $\mathrm{P}$ diet. The daily feed rationing was based on litter size. In order to minimize the effect of litter size and intake of creep feed by suckling piglets, all litters were restricted to 10 to 12 piglets and no creep feed was offered. All sows and piglets were provided ad libitum access to water. In order to avoid possible inactivation of the microbial phytases during processing, the diets were offered in mash form.

Peniophora phytase was produced by the A. oryzae strain (DSM 11857) and transformed with the phytase gene of the basidomycete strain Peniophora lycii (Cowan, 2000). This enzyme preparation had an analysed activity of $2500 \mathrm{PPU} /$ 
g and was supplied by Novozymes A/S, (Denmark) batch no. HB 9003. The Consensus phytase was encoded by a synthetic gene constructed on the basis of fungal phytase genes for high thermostability, expressed in the yeast Hansenula polymorpha. This product was delivered and specified by Hoffmann La-Roche (Switzerland) (Lot PPQ 6885). The analysed activity was 3519 PPU/g.

\section{Data recording and analysis}

The initial and final body weights as well as the feed intake of pregnant sows during the three 14-day-periods were documented. Body weights of lactating sows and suckling piglets were recorded on days 1, 7, 14 and 19 of lactation. Feed intake and possible feed refusals were documented daily. Faecal samples from pregnant sows were collected at 24-h intervals during the last 7 days of each period. During lactation, faecal samples from each sow were collected from days 15 to 19. All samples obtained on 7 (gestation) or 5 successive days (lactation) were pooled per sow and stored at $-20^{\circ} \mathrm{C}$ for subsequent lyophilization, blending, and sub-sampling for $\mathrm{Ca}, \mathrm{P}$ and $\mathrm{Cr}_{2} \mathrm{O}_{3}$ analyses. Apparent digestibility of $\mathrm{Ca}$ and $\mathrm{P}$ was measured by use of $\mathrm{Cr}_{2} \mathrm{O}_{3}(0.5 \%$ of diet) as an indicator as described by Petry and Rapp (1971). Duplicate proximate analyses were performed on all diet and faecal samples. Chemical analyses of the diets were in accordance with the official methods of VDLUFA (1988). Determination of phytase activity based on the estimation of inorganic orthophosphate released on hydrolysis of phytic acid was performed following the method described by Engelen et al. (1994). Ca was analysed by an atomic absorption spectrophotometer (Perkin Elmer, EDL System 2) according to AOAC (1984). After dry ashing, $\mathrm{P}$ was measured colorimetrically using the vanadomolybdate procedure of Tayssky and Shorr (1953) and chromium oxide $\left(\mathrm{Cr}_{2} \mathrm{O}_{3}\right)$ was determined using the method described by Brisson (1956). All data were subjected to analyses of variance as completely randomized design. Treatment means were compared using appropriate means comparison procedures (Student ttest, Wilcoxon-Mann-Whitney-test) and the significance level was set at $\mathrm{P} \geq 0.05$.

\section{RESULTS}

Analysis of phytase activity in experimental diets indicated slightly lower or higher than expected results, but the values were within an acceptable range. Peniophora phytase activities were 460, 730 and $970 \mathrm{PPU} / \mathrm{kg}$ in diets with formulated activities of 500, 750 and $1000 \mathrm{PPU} / \mathrm{kg}$, respectively. Analysed Consensus phytase activities were 588 and $1414 \mathrm{PPU} / \mathrm{kg}$ in diets formulated to contain 500 and $1000 \mathrm{PPU} / \mathrm{kg}$. 
The trials were carried out without problems and neither treatment of sows nor sow losses occurred. The body weights and apparent digestibility levels for $\mathrm{Ca}$ and $\mathrm{P}$ during gestation are presented in Table 5. The overall average body weight was in the range of $184 \mathrm{~kg}$. All of the treatments appeared to have no effect on body weight gain within the tested gestation period $\left(28^{\text {th }}\right.$ to $70^{\text {th }}$ day). The apparent $\mathrm{P}$ digestibility during the pre- and post-treatment period when all sows received the low P basal diet without phytase was identical. Consequently, the effects of advanced gestation on apparent $\mathrm{P}$ and $\mathrm{Ca}$ digestibility could be excluded and the means were used as a negative control. The overall daily feed intake of $2.1 \mathrm{~kg}$ during the treatment period provided the equivalent of 9.9 and $7.6 \mathrm{~g}$ phosphorus per sow per day for those receiving adequate or low P diets, respectively. The apparent $\mathrm{P}$ digestibility of sows receiving the adequate $\mathrm{P}$ diet was at $20.4 \%$ nearly identical to that measured for the low P diet, fed during

Table 5. Effects of dietary treatments on digestibility for $\mathrm{Ca}$ and $\mathrm{P}$ of pregnant sows

\begin{tabular}{|c|c|c|c|c|c|}
\hline Groups & & $\mathrm{A}$ & $\mathrm{B}$ & $\mathrm{C}$ & $\mathrm{D}$ \\
\hline \multicolumn{6}{|l|}{ Pre-treatment } \\
\hline number of sows & $\mathrm{n}$ & \multicolumn{4}{|c|}{20} \\
\hline body weight & $\mathrm{kg}$ & \multicolumn{4}{|c|}{$189.6 \pm 11.7$} \\
\hline daily feed intake & $\mathrm{kg}$ & \multicolumn{4}{|c|}{$2.09 \pm 0.04$} \\
\hline Digestibility & $\%$ & \\
\hline $\mathrm{Ca}$ & & \multicolumn{3}{|c|}{$22.05 \pm 4.30$} & \\
\hline $\mathrm{P}$ & & \multicolumn{4}{|c|}{$19.95 \pm 3.74$} \\
\hline \multicolumn{6}{|l|}{ Treatment } \\
\hline Peniophora phytase & PPU/kg & 0 & 500 & 750 & 1000 \\
\hline number of sows & $\mathrm{n}$ & 5 & 5 & 5 & 5 \\
\hline body weight & $\mathrm{kg}$ & $180.6 \pm 12.9$ & $189.8 \pm 7.7$ & $174.8 \pm 19.9$ & $183.8 \pm 11.1$ \\
\hline daily feed intake & $\mathrm{kg}$ & $2.05 \pm 0.03$ & $2.00 \pm 0.05$ & $2.02 \pm 0.03$ & $2.04 \pm 0.04$ \\
\hline Digestibility & $\%$ & & & & \\
\hline $\mathrm{Ca}$ & & $22.34 \pm 6.23$ & $23.88 \pm 5.27$ & $26.15 \pm 8.36$ & $29.07 \pm 7.34$ \\
\hline $\mathrm{P}$ & & $20.37 \pm 4.59^{\mathrm{a}}$ & $\begin{array}{l}22.46 \pm \\
4.38^{\mathrm{ab}}\end{array}$ & $\begin{array}{l}23.11 \pm \\
3.59^{\mathrm{ab}}\end{array}$ & $29.47 \pm 5.74^{b}$ \\
\hline \multicolumn{6}{|l|}{ Post-treatment } \\
\hline number of sows & $\mathrm{n}$ & \multicolumn{4}{|c|}{20} \\
\hline body weight & $\mathrm{kg}$ & \multicolumn{4}{|c|}{$183.5 \pm 10.3$} \\
\hline daily feed intake & $\mathrm{kg}$ & \multirow{2}{*}{\multicolumn{4}{|c|}{$2.10 \pm 0.05$}} \\
\hline digestibility & $\%$ & & & & \\
\hline $\mathrm{Ca}$ & & \multicolumn{4}{|c|}{$21.68 \pm 5.74$} \\
\hline $\mathrm{P}$ & & \multicolumn{4}{|c|}{$19.43 \pm 4.82$} \\
\hline
\end{tabular}

${ }^{a, b}$ values with different superscripts within lines are significantly different $(\mathrm{P}<0.05)$ 
the pre- and post-treatment period. With feeding graded levels of the Peniophora phytase, the apparent digestibility of $\mathrm{P}$ increased in a dose-dependent manner up to $29.5 \%$ at 1000 units per $\mathrm{kg}$ diet. Nonetheless, only the difference between the positive control and the highest dose level was significant. The improvement in $\mathrm{P}$ digestibility by adding Peniophora phytase to diets of pregnant sows up to the $70^{\text {th }}$ day of gestation is in agreement with the report of Jongbloed et al. (2004). In that study, however, P digestibility in all treatments was lower than in the presented results. The digestibility of Ca was also improved up to $30.1 \%$ when compared with sows without supplementation. Despite the differences being in contrast to Jongbloed et al. (2004), they were not significant.

The performance data measured during the 19-day-lactation period are summarized in Tables 6 and 7. The mean litter size was 10.6 piglets per sow. The overall feed intake during the experimental period was in the range of $87.2 \mathrm{~kg}$ for all groups, which was equivalent to a daily feed intake of $4.6 \mathrm{~kg}$ per sow. With regard to daily total $\mathrm{P}$ intake this corresponded to 27.3 or $15.9 \mathrm{~g}$ per sow for the adequate or low $\mathrm{P}$ supply, respectively.

Consequently, the daily total $\mathrm{P}$ intake was 22 and 54.6 , or 13.3 and $49.5 \%$ lower than the adequate P supply of 35 or $31.5 \mathrm{~g}$ per sow and day given by GfE (1997) or NRC (1998).

Piglets from sows fed the Consensus phytase diets gained $14.9 \%$ more weight than those on the low P diet without supplementation. This effect, however, was below the level of statistical significance. Taking into account that piglets received no creep feed and that about $4.3 \mathrm{~kg}$ milk is needed per $\mathrm{kg}$ body weight gain, the calculated daily milk production of sows fed the adequate or low P diet without phytase supplementation amounted on average to 12.2 or $10.1 \mathrm{~kg}$ milk per sow

Table 6. Effects of dietary treatments on body weight and feed intake during the lactation period ( $1^{\text {st }}$ to $19^{\text {th }}$ day) (Values per sow)

\begin{tabular}{lccccc}
\hline Treatment & & $\mathrm{A}$ & $\mathrm{B}$ & $\mathrm{C}$ & $\mathrm{D}$ \\
\hline $\begin{array}{l}\text { Consensus phytase } \\
\text { Sows }\end{array}$ & $\mathrm{PPU} / \mathrm{kg}$ & 0 & 0 & 500 & 1000 \\
$\begin{array}{l}\text { Body weight, day } \\
\quad \mathrm{n}\end{array}$ & $\mathrm{kg}$ & & 6 & 6 & 6 \\
$\quad 1^{\text {st }}$ & & $223 \pm 13$ & $221 \pm 31$ & $220 \pm 9.3$ & $218 \pm 7$ \\
$\quad 7^{\text {th }}$ & & $220 \pm 16$ & $220 \pm 30$ & $217 \pm 10$ & $214 \pm 7$ \\
$\quad 4^{\text {th }}$ & & $214 \pm 17$ & $216 \pm 33$ & $215 \pm 10$ & $212 \pm 8$ \\
$\quad 9^{\text {th }}$ & & $211 \pm 15$ & $213 \pm 36$ & $213 \pm 8$ & $211 \pm 7$ \\
$\begin{array}{l}\text { Body weight } \\
\text { difference }\end{array}$ & & & & & \\
$\quad 1^{\text {st }}$ to $19^{\text {th }}$ day & $\mathrm{kg}$ & $-12 \pm 6$ & $-9 \pm 10$ & $-7 \pm 4$ & $-7 \pm 2$ \\
$\begin{array}{l}\text { Litter size } \\
\text { Total feed intake }\end{array}$ & $\mathrm{n}$ & $11.2 \pm 1.6$ & $10.7 \pm 1.2$ & $10.7 \pm 0.8$ & $10.0 \pm 0.0$ \\
\hline
\end{tabular}


Table 7. Effects of dietary treatment of lactating sows on body weight gain of piglets during the lactation period ( $1^{\text {st }}$ to $19^{\text {th }}$ day) (Values per piglet)

\begin{tabular}{|c|c|c|c|c|c|}
\hline Treatment & & A & B & $\mathrm{C}$ & $\mathrm{D}$ \\
\hline Consensus phytase & $\mathrm{PPU} / \mathrm{kg}$ & 0 & 0 & 500 & 1000 \\
\hline Litter size & $\mathrm{n}$ & $11.2 \pm$ & $10.7 \pm$ & $10.7 \pm$ & $10.0 \pm 0.0$ \\
\hline Body weight, day & $\mathrm{kg}$ & & & & \\
\hline $1^{\text {st }}$ & & $1.68 \pm 0.37$ & $1.70 \pm 0.23$ & $1.51 \pm 0.34$ & $1.72 \pm 0.38$ \\
\hline $3^{\text {rd }}$ & & $1.96 \pm 0.39$ & $2.07 \pm 0.22$ & $1.98 \pm 0.59$ & $2.23 \pm 0.42$ \\
\hline \multicolumn{6}{|l|}{ Body weight gain, day } \\
\hline $1^{\text {st }}$ to $3^{\text {rd }}$ & $\mathrm{kg}$ & $0.28 \pm 0.17$ & $0.37 \pm 0.19$ & $0.47 \pm 0.47$ & $0.51 \pm 0.29$ \\
\hline Body weight $7^{\text {th }}$ day & $\mathrm{kg}$ & $2.86 \pm 0.62$ & $2.98 \pm 0.41$ & $2.85 \pm 0.71$ & $3.23 \pm 0.50$ \\
\hline Body weight gain, day & $\mathrm{kg}$ & & & & \\
\hline $3^{\text {rd }}$ to $7^{\text {th }}$ & & $0.90 \pm 0.36$ & $0.91 \pm 0.39$ & $0.87 \pm 0.66$ & $1.00 \pm 0.41$ \\
\hline Body weight $14^{\text {th }}$ day & $\mathrm{kg}$ & $4.33 \pm 0.83$ & $4.30 \pm 0.71$ & $4.42 \pm 1.01$ & $4.94 \pm 0.69$ \\
\hline Body weight gain, day & $\mathrm{kg}$ & & & & \\
\hline $7^{\text {th }}$ to $14^{\text {th }}$ & & $1.47 \pm 0.49$ & $1.31 \pm 0.48$ & $1.57 \pm 0.54$ & $1.71 \pm 0.62$ \\
\hline Body weight $19^{\text {th }}$ day & $\mathrm{kg}$ & $6.26 \pm 1.16$ & $5.86 \pm 0.71$ & $6.28 \pm 1.20$ & $6.50 \pm 0.84$ \\
\hline Body weight gain, day & $\mathrm{kg}$ & & & & \\
\hline $14^{\text {th }}$ to $19^{\text {th }}$ & & $1.93 \pm 0.74$ & $1.57 \pm 0.43$ & $1.86 \pm 0.54$ & $1.57 \pm 0.59$ \\
\hline $1^{\text {st }}$ to $19^{\text {th }}$ & & $4.58 \pm 1.01$ & $4.16 \pm 0.77$ & $4.77 \pm 1.05$ & $4.79 \pm 0.76$ \\
\hline
\end{tabular}

per day during 19 days of lactation. Based on the improved body weight gain in the range of $0.62 \mathrm{~kg}$ per piglet of sows fed with Peniophora phytase, the daily milk production was possibly increased by about $1.1 \mathrm{~kg}$ per sow per day when compared with the sows receiving the low $\mathrm{P}$ diet without phytase. The results for the apparent digestibility of $\mathrm{P}$ and $\mathrm{Ca}$ measured during the $15^{\text {th }}$ to $19^{\text {th }}$ days of lactation are presented in Table 8. Overall, the data were higher when compared with the pregnancy and reflected the enhanced $\mathrm{P}$ requirement during lactation.

Table 8. Effects of dietary treatments of lactating sows on apparent digestibility of $\mathrm{Ca}$ and $\mathrm{P}$ (Values per sow)

\begin{tabular}{llllcc}
\hline Treatment & & $\mathrm{A}$ & $\mathrm{B}$ & $\mathrm{C}$ & $\mathrm{D}$ \\
\hline Consensus phytase & $\mathrm{PPU} / \mathrm{kg}$ & 0 & 0 & 500 & 1000 \\
Sows number & $\mathrm{n}$ & 6 & 6 & 6 & 6 \\
Digestibility & & & & & \\
$\quad \mathrm{Ca}$ & $\%$ & $58.8 \pm 2.6$ & $59.6 \pm 3.7$ & $60.6 \pm 3.6$ & $63.0 \pm 2.0$ \\
$\quad \mathrm{P}$ & $\%$ & $47.9 \pm 1.6^{\mathrm{ac}}$ & $40.7 \pm 5.3^{\mathrm{a}}$ & $55.0 \pm 7.5^{\mathrm{bc}}$ & $62.6 \pm 3.9^{\mathrm{b}}$ \\
\hline values with different superscripts within lines are significantly different
\end{tabular}


Phytase-dependent effects can not be excluded, however, because during gestation and lactation, the diets were supplemented with different phytases.

The apparent digestibility of $\mathrm{P}$ differed between sows fed with the adequate $\mathrm{P}$ level and those who received the low $\mathrm{P}$ diet without phytase, which was obviously due to the better availability of MCP-P. Consensus phytase improved P digestibility in the range of $15 \%$ at 500 and $30 \%$ at 1000 units per $\mathrm{kg}$ diet when compared with the positive control. Jongbloed et al. (2004) also reported an increase in P digestibility when Peniophora phytase was added at 750 and 1000 units per $\mathrm{kg}$ diet. The measured digestible $\mathrm{P}$ for sows receiving adequate or low P diets was 2.8 and $1.4 \mathrm{~g}$ per $\mathrm{kg}$ feed, which confirmed the calculated P digestibilities based on the digestibility factors published by Jongbloed and Kemme (1990). The data indicate a trend towards an increase in Ca digestibility with graded levels of phytase supplementation. This effect was, however, below the level of statistical significance due to high variation. The $P$ and $C$ a digestibility values of lactating sows were higher than those reported by Jongbloed at al. (2004). Possible explanations could be differences in the diets and the higher $\mathrm{P}$ intake in the range of 34 and $41.5 \%$ for adequate and low P supply, respectively.

\section{DISCUSSION}

The results of the current study clearly indicate that phytase supplementation with the commercially available Peniophora phytase during gestation and with the Consensus phytase during lactation was effective in improving the digestibility of phytate $\mathrm{P}$ as well as, to some extent, that of $\mathrm{Ca}$ in low $\mathrm{P}$ diets for sows. Furthermore, the results point towards an improvement in growth performance of suckling piglets, possibly caused by higher milk production of sows fed diets with Consensus phytase, because no creep feed was offered. When compared with piglets, the contribution of the large intestine's higher microbial activities to intestinal nutrient conversion is, under the conditions of the present study, without relevance for higher $\mathrm{P}$ availability. When comparing experimental data, pregnant and lactating sows receiving the adequate $\mathrm{P}$ diets had respective daily intakes of 2.0 and $13.1 \mathrm{~g}$ per sow and day. The adequate $\mathrm{P}$ diets were, therefore, 50 and $27.2 \%$ lower than the recommended levels (GfE, 1997). Pregnant and lactating sows fed the low P diet without phytase were provided with 1.5 and $6.5 \mathrm{~g}$ of available $\mathrm{P}$ per sow and day. When compared with the adequate level, the intake of available $\mathrm{P}$ was reduced by 25 and 50.4\%. In their study, Jongbloed et al. (2004) measured $\mathrm{P}$ digestibility rates of 16.3 and 13.9 , or 26.7 and $21.7 \%$, on the $70^{\text {th }}$ and $100^{\text {th }}$ days of pregnancy for the positive $(5.2 \mathrm{~g} \mathrm{P} / \mathrm{kg})$ and negative controls $(3.9 \mathrm{~g} \mathrm{P} / \mathrm{kg})$, respectively. Differences in $\mathrm{P}$ digestibility during pregnancy were not consistent 
with the results of the current study measured on days 49 to 69 of pregnancy, because no pronounced differences between the $49^{\text {th }}$ and $69^{\text {th }}$ day of pregnancy could be found in sows fed unsupplemented diets. In a comparable study on lactating sows that were fed either 6.8 or $5.1 \mathrm{~g}$ P per $\mathrm{kg}$ diet, $\mathrm{P}$ digestibility was in the respective ranges of 34.9 and $21.4 \%$ (Jongbloed et al., 2001, 2004). During lactation, the $\mathrm{P}$ supply in the adequate and low $\mathrm{P}$ diets was, with 5.9 and $3.4 \mathrm{~g}$ per $\mathrm{kg}$ diet, lower than otherwise reported. Therefore, the higher $\mathrm{P}$ digestibility of 48 and $41 \%$ found in this study was probably due to the lower P supply. During pregnancy, the overall $\mathrm{Ca}$ intake of $14.8 \mathrm{~g}$ per sow per day slightly exceeded the recommended supply (GfE, 1987). During lactation, however, the Ca intake with an average of $42.8 \mathrm{~g}$ per sow per day was $14.4 \%$ lower than the recommended level of $50 \mathrm{~g}$ (GfE, 1987), although in comparison with NRC (1998), it was 8.6\% higher. The relationship between $\mathrm{Ca}$ and $\mathrm{P}$ for gestating and lactating sows fed the adequate vs low $P$ diet was $1.46: 1$ and $1.96: 1$. vs $1.53: 1$ and $2.74: 1$. In contrast to chickens (Mohammed et al., 1991), gestating and lactating sows showed a varied response to $\mathrm{P}$ digestibility, which seemed to be less dependent on Ca intake than on lowering the dietary $\mathrm{P}$ level. The phytases supplemented during pregnancy and lactation were different, however, and therefore substrate effects can not be excluded. The differences in $\mathrm{P}$ digestibility between the positive and negative controls with or without monocalcium-phosphate were smaller than expected. This could be due to the relatively small amounts of monocalcium-phosphate in the diets. Diets enhanced with supplementation of Peniophora phytase at 500, 750,1000 units $/ \mathrm{kg}$ feed for gestating, and Consensus phytase at 500 and 1000 units $/ \mathrm{kg}$ feed for lactating sows in the range of 21.2 to $47.6 \%$ and 35.1 to $53.8 \%$ showed a dose-dependent improvement of digestibility in comparison with the respective low $\mathrm{P}$ diets without phytase supplementation. Comparable effectivities were found for pregnant sows by Jongbloed and Kemme (2002) and Jongbloed et al. (2004). During lactation, however, phytase effectiveness was lower than that found by Jongbloed et al. $(2001,2004)$. When feeding the Peniophora phytase at 750 and 1000 units per $\mathrm{kg}$ diet, the amount of digestible $\mathrm{P}$ in the diet for pregnant sows increased by 0.1 and $0.53 \mathrm{~g}$ per $\mathrm{kg}$ diet, which was equivalent to 0.6 and 2.9 g MCP-P per $\mathrm{kg}$ diet ( $220 \mathrm{~g}$ total $\mathrm{P}$ per $\mathrm{kg}$, digestibility $82 \%$ ). The addition of Consensus phytase at 500 and 1000 units per kg in diets for lactating sows resulted in significant improvement in P digestibility by 0.46 and $0.73 \mathrm{~g}$ per $\mathrm{kg}$ feed, which corresponds to $2.5 \mathrm{~g}$ or $4.0 \mathrm{~g}$ MCP-P per kg diet, respectively. The higher supplementation level of both phytases resulted in a lower equivalence per unit of phytase.

Another point worthy of consideration is that with regard to P digestibility of phytate-P, the Consensus phytase was more effective than the Peniophora phytase. The $\mathrm{pH}$ optima of both phytases were between $\mathrm{pH} 4.5$ to 5.5 (Simon 
and Igbasan, 2002) meaning, therefore, that they can only act effectively in the stomach. Consequently, other properties or factors may have been responsible for the different effectivities. The reason behind this is most probably the higher resistance of the Consensus phytase to inactivation by pepsin or stomach supernatant (Simon and Igbasan, 2002). A possible explanation for the different phytase effectivities, however, could also be due to differences in composition of the diets, phytase activities, physiological status, and differing P requirements between gestating and lactating sows.

\section{CONCLUSIONS}

Consistent with the report of Jongbloed and Kemme (2002) who studied an Aspergilus ficuum phytase (expressed in A. niger) for its effectiveness in pregnant and lactating sows, the results of the current experiment suggest that the fungal phytases used in this study are effective to a similar degree, as also shown by Jongbloed et al. (2004). Furthermore, phytase-mediated hydrolysis of phytatebound $\mathrm{P}$ in diets for gestating and, especially, for lactating sows seems to be as effective as in diets for growing piglets.

\section{REFERENCES}

AOAC, 1984. Official Methods for Analysis, Association of Official Analytical Chemists. 14 ${ }^{\text {th }}$ Edition. Arlington, VA

Brisson G.J., 1956. On the routine determination of chromium oxide in feeds. Can. J. Agr. Sci. 36, 210-211

Cowan W.D., 2000. New developments with phytase. In: Aktuelle Themen der Tierernährung und Veredlungswirtschaft. Wissenschaftliche Tagung 27-28 October 1999, Cuxhaven, Lohmann Animal Health

Eeckhout W., De Paepe M., 1994. Total phosphorus, phytate-phosphorus and phytase activity in plant feedstuffs. Anim. Feed Sci. Tech. 47, 19-29

Engelen A.J., van der Heeft F.C., Randsdorp H.G., Smit E.L.C., 1994. Simple and rapid determination of phytase activity. J. AOAC. Int. 77, 760-764

Erdmann J.W., 1979. Oilseed phytases: Nutritional implications. J. Amer. Oil Chem. Soc. 56, 736 $-741$

GfE (Ausschuss für Bedarfsnormen der Gesellschaft für Ernährungsphysiologie), 1987. Energie und Nährstoffbedarf landwirtschaftlicher Nutztiere. Nr.4, Schweine. DLG Verlag, Frankfurt (Main)

GfE(Ausschuss für Bedarfsnormen der Gesellschaft für Ernährungsphysiologie), 1997. Überarbeitete Empfehlungen zur Versorgung von Schweinen mit Phosphor. Proc. Nutr. Soc. 6, 193-200

Jongbloed A.W., Kemme P.A., 1990. Apparent digestible phosphorus in the feeding of pigs in relation to availability, requirement and environment. 1. Digestible phosphorus in feedstuffs from plant and animal origin. Neth. J. Agr. Sci. 38, 567-575

Jongbloed A.W., Kemme P.A., 2002. Phosphor-Versorgung von Schweinen ohne Futtermittel tierischer Herkunft. Lohmann Informationen 1-2002, pp. 8-15 
Jongbloed A.W., van Diepen J.Th. M., Kemme P.A., Broz J., 2004. Efficacy of microbial phytase on mineral digestibility in diets for gestating and lactating sows. Livest. Prod. Sci. 91, 143- 155

Jongbloed A.W., van Diepen J.Th.M., Kemme P.A., Dias H., Broz J., 2001. Efficacy of microbial phytase in diets for lactating sows and on reduction of phosphorus excetion. Short paper N5.5, Book of Abstracts No. 7, 52 ${ }^{\text {nd }}$ Annual Meeting EAAP, Budapest (Hungary), p. 122

Kemme P.A., Jongbloed A.W., Mroz Z., Reynen A.C., 1997. The efficacy of Aspergillus niger phytase in rendering phytate phosphorus available for absorption in pigs is influenced by pig physiological status. J. Anim. Sci. 75, 2129-2138

Lehmann M., Pasamontes L., Lassen S.F., Wyss M., 2000. The consensus concept for thermostability engineering of proteins. Biochim. Biophys. Acta. 1543, 408-415

Liesegeng A., Loch L., Risteli J., 2005. Influence of phytase added to a vegetarian diet on bone metabolism in pregnant ant lactating sows. J. Anim. Physiol. Anim. Nutr. 89, 120-128

Maga J.A., 1982. Phytate: Its chemistry, occurrence, food interactions, nutritional significance, and methods of analysis. J. Agr. Food Chem. 30, 1-9

Mohammed A., Gibney M.J., Taylor T.G., 1991. The effects of dietary levels of inorganic phosphorus, calcium and cholecalciferol on the digestibility of phytate P by the chick. Brit. J. Nutr. 66, 251259

NRC (National Research Council), 1998. Nutrient Requirements of Swine. 10 $0^{\text {th }}$ revised Edition. National Academy Press. Washington, DC

Petry H.H., Rapp W., 1971. Zur Problematik der Chromoxidbestimmung in Verdauungsversuchen. Z. Tierphysiol. Tierernähr. 27, 181-189

Poulsen H.D., Jongbloed A.W., Latimier P., Fernandez J.A., 1999. Phosphorus consumption, utlization and losses in pig production in France, the Netherlands and Denmark. Livest. Prod. Sci. 58, 251-259

Simon O., Igbasan F., 2002. In vitro properties of phytase from various microbial origins. Int. J. Food Sci. Tech. 37, 813-822

Tayssky H.H., Shorr E., 1953. A microcolorimetric method for the determination of inorganic phosphorus. J. Biol. Chem. 202, 675-685

Van der Klis J.D., Versteegh H.A.J., 2001. Phosphorus in nutrition of poultry. In: Recent Developments in Poultry Nutrition 2. J. Wiseman, P.C. Garnsworthy (Editors). Nottingham University Press, pp. 309-320

VDLUFA, 1988. Die chemische Untersuchung von Futtermitteln. Methodenbuch Band III., VDLUFA-Verlag Darmstadt 
